\title{
Fossil spiders (Araneae) from the Eocene Green River Formation of Colorado
}

\author{
Ископаемые пауки (Araneae) эоџеновой свиты Грин-Ривер \\ из Колорадо
}

\author{
Paul A. Selden ${ }^{1,2} \&$ Yinan Wang 3 \\ П. Семден ${ }^{1,2}$, Й. Вань ${ }^{3}$
}

\author{
'Paleontological Institute and Department of Geology, University of Kansas, 1475 Jayhawk Boulevard, Lawrence, Kansas 66045, USA \\ ${ }^{2}$ Natural History Museum, Cromwell Road, London SW7 5BD, UK. E-mail: selden@ku.edu \\ ${ }^{3}$ P.O. Box 2882, Arlington, Virginia 22202, USA. E-mail: veomega@gmail.com
}

KEY WORDS: Cenozoic, Hersiliidae, Hersiliola, Miagrammopes, Selenopidae, Thomisidae, Uloboridae, Ypresian.

КЛЮЧЕВЫЕ СЛОВА: Кайнозой, отпечатки, Hersiliidae, Hersiliola, Miagrammopes, Selenopidae, Thomisidae, Uloboridae, Ипрский ярус.

ABSTRACT. Ten specimens of spiders from the Eocene (c. 49-50 Ma) Parachute Creek Member of the Green River Formation from Colorado are reported. None is sufficiently well preserved to be described as a new taxon. Spiders belonging to the Uloboridae (including Miagrammopes), Hersiliidae (Hersiliola), Selenopidae, and Thomisidae are described and illustrated. These extend the fossil record of Hersiliola, Miagrammopes and Thomisidae. The Parachute Creek Member is a cyclical sequence of oil shales and evaporites which represents intermittent playa lake sediments. The arachnofauna of varied modes of life, possibly from a variety of habitats, was most likely preserved during flash flood episodes.

РЕЗЮМЕ. Отмечено 10 видов пауков из эоценовых отложений Парашют-Крик пачки в свите Грин-Ривер в Колорадо. Ни один из видов не сохранился достаточно хорошо для полноценного описания. Описаны и проиллюстрированы пауки, относящиеся к Uloboridae (включая Miagrammopes), Hersiliidae (Hersiliola), Selenopidae и Thomisidae. Отпечатки Hersiliola, Miagrammopes и Thomisidae найдены впервые. Пачка Парашют-Крик являет собой цикличную последовательность нефтеносных глинистых сланцев и эвапоритов, представляющие собой чередующиеся прибрежные озёрные отложения. Пауки различных экологических группировок, живших, по всей вероятности в разных биотопах, очевидно были захоронены в периоды резких наводнений.

\section{Introduction}

Spiders are relatively common in some members of the Eocene Green River Formation of Wyoming, Utah, and Colorado, yet hitherto only a single specimen has been described: Linyphia byrami Cockerell, 1925. Some legs and eggsacs, supposedly of araneids, were described and figured (but not named) by Scudder [1890], and illustrations of Green River spiders have appeared in, for example, Dayvault et al. [1995] and Grande [2013]. Most of these are misidentified. Here, we describe a few, identifiable specimens from a collection of fossil spiders from the Ypresian (49-50 Ma: Smith et al. [2008]) Parachute Creek Member of the Green River Formation, Rio Blanco County, Colorado.

Cenozoic spiders are far more common than those from older strata, particularly because of their relative abundance in ambers from the Baltic region of Europe, the Dominican Republic, and elsewhere. However, spiders preserved in the rock matrix, usually lake deposits, are considerably rarer, and their interest lies in that the arachnofaunas preserved do not necessarily come from forests. Moreover, the oldest of the major Cenozoic ambers, the Baltic amber, is slightly younger (c. 40-49 Ma: Weitschat \& Wichard [2010]) than the Green River Formation, so the specimens described in this paper are among the oldest known fossils of their respective taxa.

In this paper, we present an overview of the Parachute Creek Member of the Eocene Green River Formation, description of a selection of specimens of spiders from this horizon, and comments on the palaeoenvironment which is suggested by this arachnofauna.

\section{Stratigraphy and palaeontology}

The specimens come from the Parachute Creek Member of the Green River Formation, from Rio Blanco County, Colorado (site B in Dayvault et al. [1995]). This horizon, approximately $45 \mathrm{~m}$ below the Mahoga- 

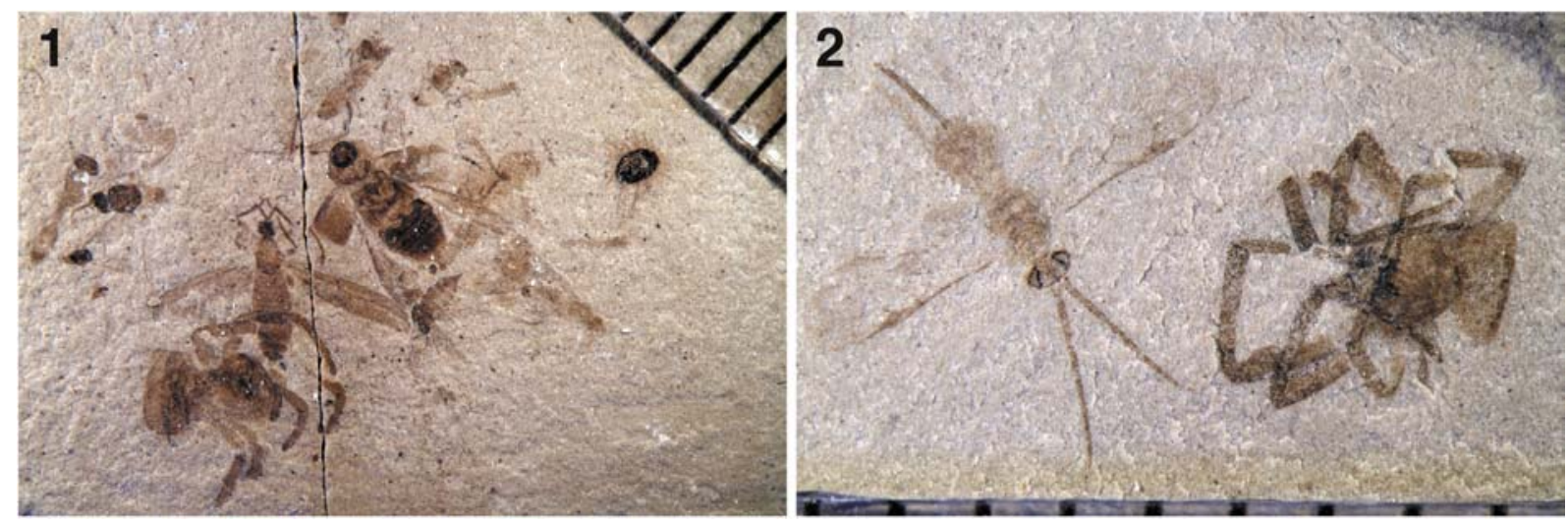

Figs 1-2. Typical preservation of insects and spiders in the Parachute Creek Member of the Eocene Green River Formation, dry, scale lines are mm: 1 - KUMIP 366472, insects and juvenile thomisid spider; 2 - KUMIP 366470b, male thomisid spider and adjacent hymenopteran.

Рис. 1-2. Пример типичных отпечатков насекомых и пауков в пачке Парашют-Крик свиты Грин-Ривер, сухая поверхность, шкала в мм: 1 - KUMIP 366472, насекомые и ювенильный паук-бокоход; 2 - KUMIP 366470b, самец паука-бокохода и перепончатокрылое.

ny Bed, is dated as Lower Eocene (Ypresian), approximately 49-50 Ma (Smith et al. [2008]).

The Green River Formation is famous for its spectacular fossil plants, insects, crocodiles, and rare birds and mammals, including a bat [Nudds \& Selden, 2008]. Other arachnids reported include a scorpion Uintascorpio halandrasorum Perry, 1995 [Santiago-Blay et al., 2004], and a chelytid mite [Bradley, 1931], although the latter may be a Recent contaminant. Many of the specimens described here have insects adjacent to or lying across the spider; some specimens bear more than one spider or other arachnid on the slab. It is tempting to assume that insects lying across or adjacent to the spider (Figs 1-2) were in the process of being eaten or stalked; on the contrary, the likelihood of a random association is high. One example of an accumulation of insects adjacent to a spider was published as a possible example of a fossilized web with its prey [Coddington, 1995], although no silk is preserved.

The fossil record of uloborids is long-ranging, extending back to the Cretaceous at least, and possibly Jurassic [Selden \& Beattie, 2013]. Cenozoic uloborids, however, are known only from ambers, and the genus Miagrammopes O. Pickard-Cambridge, 1870 is known from Neogene Dominican amber and Quaternary copal of Madagascar [Dunlop et al., 2014]. The Miagrammopes sp. described here is thus the oldest record of the genus. The hersiliid fossil record extends back to the Cretaceous, with a record in Burmese amber [Wunderlich, 2011]; nevertheless, the fossil reported here is the oldest known record of the genus Hersiliola Thorell, 1870. Selenopidae are known from Quaternary copal of Madagascar, Baltic amber, and amber from the Paris Basin [Dunlop et al., 2014]. The last record [Penney, 2006], from the locality of Le Quesnoy, is dated as early Eocene (52-55 Ma: Nel \& Brasero [2010]) in age, and is thus slightly older than the Green River record described here. Finally, the fossil record of Thomisidae is entirely Cenozoic, with records from the major amber and copal deposits, as well as from lake sediments in Colorado, Alaska, Wyoming, China, Germany, Italy, and France [Dunlop et al., 2014]. The strata in none of these localities is as old as the Green River, so the fossils described here are the oldest thomisids known from the fossil record.

The fossil horizon lies within the Piceance Basin, an enclosed lake during early Eocene times, which was subject to cyclical evaporative episodes, of which the Parachute creek Member is one [Smith et al., 2008]. Consequently, many of the spider specimens died with their legs curled, an attitude consistent with hypersaline environments [Downen \& Selden, 2013]. How such fauna as terrestrial arthropods came to be preserved in such an environment is the subject of speculation. Possibly, they were living on mud flats adjacent to a saline lake and were occasionally incorporated into a flash flood which enlarged the lake temporarily, drowning and preserving the spiders in a saline medium.

\section{Material and methods}

The fossil spiders described here come from a collection of 54 specimens loaned by YW to PAS, of which ten were selected for study because they were better preserved and recognizable, to some extent. Among the collection is also a tiny juvenile opilionid, too poorly preserved to say more than that. The fossils are preserved as patches of organic matter on thin slabs of siltstone. In general, the setae and other more robust (i.e. two layers of cuticle when compressed in the rock) are best preserved. In some specimens (e.g. KUMIP 366475 ) the organic matter has degraded so that it is partly just a ghostly shape; nevertheless, some specimens like this provide data. The preservation is not sufficiently good for fine structures such as trichobothria (except in one case: Fig. 27) to be seen. 
The specimens were studied and photographed under $70 \%$ ethanol (to enhance contrast) using a Leica MZ16 stereomicroscope, and photographed using a Canon EOS 5D MkIII digital camera attached to the microscope and DSLR Assistant software (www. kaasoft.com) on an Apple MacBook Pro computer. Photographs were manipulated using Adobe Photoshop software, and final drawings were made from the photographs using iDraw (www.indeeo.com). Except for Figs 1-2, all photographs were taken under $70 \%$ ethanol. All measurements are in millimetres and were made from the drawings using iDraw. Measurements of paired organs are means of left and right of part and counterpart, i.e. maximally four measurements if all are preserved, and means are presented in the descriptions.

Leg formula (e.g. 1423) indicates the length of each leg relative to the others, from longest to shortest. Abbreviations: at anal tubercle, AS anterior spinneret, cal calamistrum, car carapace, ch chelicera, e embolus, ep epigyne, fe femur, L length, lb labium, mc median claw, mt metatarsus, mx maxilla, op opisthosoma, pc paired claw, pa patella, Pd pedipalp, PS posterior spinneret, sp spinnerets, st sternum, ta tarsus, ti tibia, tr trichobothrium, W width. Repository abbreviation: KUMIP - Kansas University Museum of Natural History, Division of Invertebrate Paleontology.

\section{Taxonomic survey}

\section{Order Araneae Clerck, 1757}

Suborder Opisthothelae Pocock, 1892

Infraorder Araneomorphae Smith, 1902

Entelegynae Simon, 1893

\section{Family Uloboridae Thorell, 1869}

REMARKS. The specimens described here are placed in this family on account of them being cribellate, the legs being thickly clothed in coarse setae, with few, small macrosetae, apart from the characteristic row of short macrosetae on the ventral surface of the tarsus and distal metatarsus of Leg IV [Opell, 1979; Griswold et al., 2005] (seen in Miagrammopes sp.).

\section{Uloboridae incertae sedis}

Figs 3-8.

REMARKS. KUMIP 366476 lacks details which would place it in any particular uloborid genus, though its general features suggest it belongs in this family; the calamistrum, and coarse setae and few, small macrosetae on the legs, for example. The elongate legs 1 and 2, and very short leg III suggest this was an orb weaver. The swollen but unerupted pedipalps indicates that it is a juvenile male. The fourth leg is seen only as shadows hidden beneath the opisthosoma in the counterpart; nevertheless, a section of calamistrum can be seen (Fig. 8). The difference in leg formula and leg lengths preclude this spider from belonging to the same species as the following (Miagrammopes sp.).

MATERIAL. KUMIP 366476a (part) and 366476b (counterpart) (subadult male) from the Lower Eocene (Ypresian: 49-50 Ma) Parachute Creek Member of the Green River Formation, from Rio Blanco County, Colorado.

DESCRIPTION. KUMIP366476. Juvenile male. Body elongate, L 3.81. Slightly swollen pedipalp tarsi with curved macrosetae. Leg formula 1243; legs thickly clothed in coarse setae; few, small macrosetae on ti and $\mathrm{mt}$ of all legs; section of cal on $\mathrm{mt} 4$ of counterpart (Fig. 8); podomere lengths: Leg I fe 2.88, pa 0.48, ti 2.43 , mt 1.92, ta 1.15; Leg II fe 1.97 , pa 0.39 , ti 1.51 , mt 1.21, ta 0.74 ; Leg III ti 0.62 , mt 0.55 , ta 0.50 ; Leg IV ti $1.55, \mathrm{mt}+$ ta 1.88 . Op L 2.59, W $1.48(\mathrm{~L} / \mathrm{W}$ ratio 1.75); sp subterminal, short (Fig. 7).

Genus Miagrammopes O. Pickard-Cambridge, 1870

\section{Miagrammopes sp.}

$$
\text { Figs 9-19. }
$$

REMARKS. The elongate opisthosoma with terminal spinnerets, flat carapace, and massive forelegs and relatively tiny second and third legs place this species within the genus. KUMIP 366473 is considered to be a female on account of the inconspicuous pedipalps and the raised area of the opisthosoma in the epigynal region. KUMIP 366474 and KUMIP 366475 are subadult males, based on the swollen but unerupted pedipalps. It is not possible to distinguish the fossils from other members of the genus, so the species is recorded here as Miagrammopes sp.

MATERIAL. KUMIP 366473a (part) and 366473b (counterpart) (female), KUMIP 366474 and KUMIP 366475 (subadult males) from the Lower Eocene (Ypresian: 49-50 Ma) Parachute Creek Member of the Green River Formation, from Rio Blanco County, Colorado.

DESCRIPTION. KUMIP 366473 (Figs 9-12, 17). Female. Body elongate, L 4.75; car L 1.52. Leg formula 1423; legs thickly clothed in coarse (presumably plumose) setae, no macrosetae except characteristic uloborid row of short macrosetae along ventral edge of ta 4 and distal mt 4 (Fig. 17); fragment of cal on dorsal edge of $\mathrm{mt} 4$ of part (Fig. 17); podomere lengths: Leg I fe 2.34 , pa 0.51 , ti 1.58 , mt 2.01, ta 0.76 ; Leg II pa 0.33 , ti 0.75 , mt 0.65 , ta 0.50 ; Leg III mt 0.61 , ta 0.37 ; Leg IV 1.38 , pa 0.42 , ti 1.41 , mt 0.80 , ta 0.91 . Op cylindrical, L 3.24, W 0.81 (L/W ratio 4.26); cluster of terminal spinnerets.

KUMIP 366474 (Figs 13-14). Subadult male. Body elongate, L 3.80; car L 0.98. Leg formula 1423; podomere lengths: Leg I fe 2.19, pa 0.53, ti 1.76, mt 1.95, ta 1.08; Leg II fe 0.90 , pa 0.24 , ti 0.70 , mt 0.78 , ta 0.56 ; Leg IV fe 1.45 , ti 0.89 , mt 0.83 , ta 0.72 . Op L 2.82, W 0.79 (L/W ratio 3.58).

KUMIP 366475 (Figs 15-16, 18-19). Subadult male. Body elongate, L 4.94; car L 1.60, W 0.96 (L/W ratio 1.66). Leg formula 1423; cal L 0.60 , stretching from $0.15 \%$ to $0.61 \%$ of length of $\mathrm{mt}$ (Fig. 18); podomere lengths: Leg I fe 2.42, pa 0.51; Leg II fe 1.19 , pa 0.42 , ti 1.52 , mt 1.47 ; Leg III fe 0.97 ; pa 0.26 , 

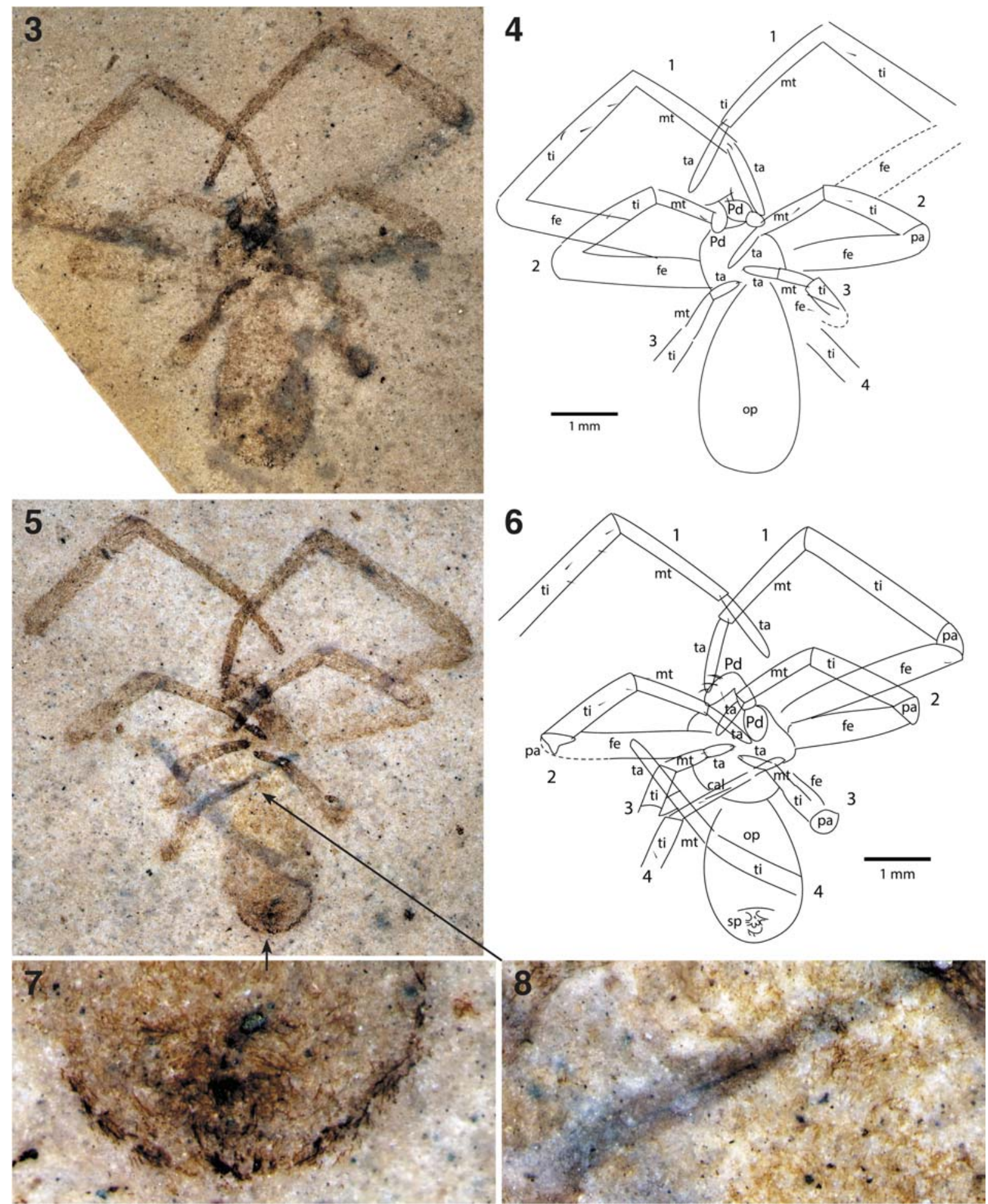

Figs 3-8. Uloboridae incertae sedis, juvenile male, KUMIP 366476a (part, 3-4), KUMIP 366476b (counterpart, 5-8): 3, 5 photographs of whole specimens; 4, 6 - explanatory drawings of 3 and 5 , respectively; 7 - spinneret region; 8 - calamistrum on left leg IV of counterpart.

Pис. 3-8. Uloboridae incertae sedis, ювенильный самец, KUMIP 366476a (отпечаток, 3-4), KUMIP 366476b (противоотпечаток, 5-8): 3, 5 - фотографии всего тела; 4, 6 - поясняющие рисунки фотографий 3 и 5, соответственно; 7 - область паутинных бородавок; 8 - каламиструм ноги IV противоотпечатка. 


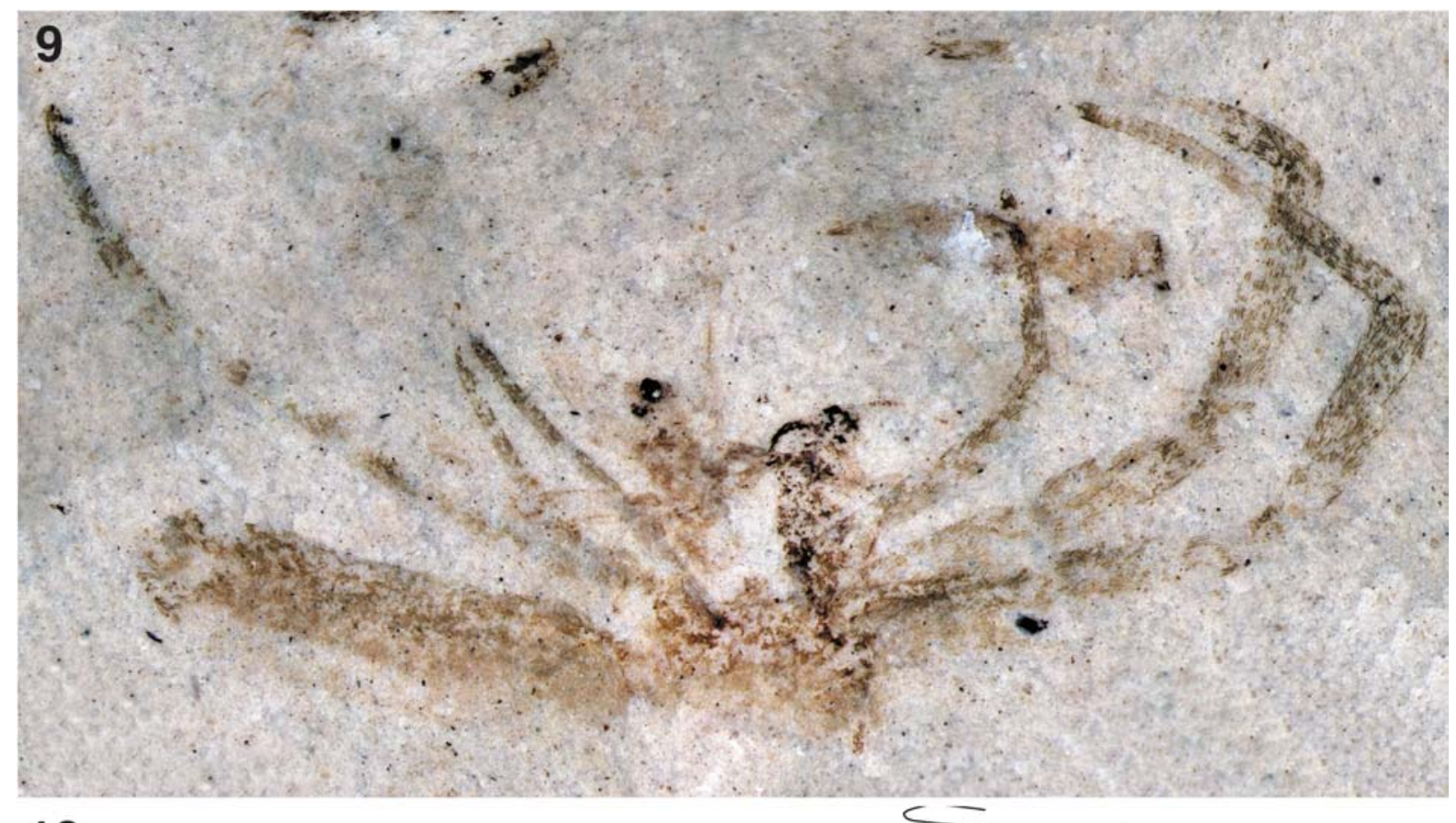

10

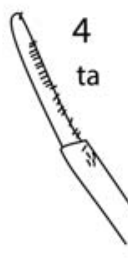

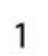



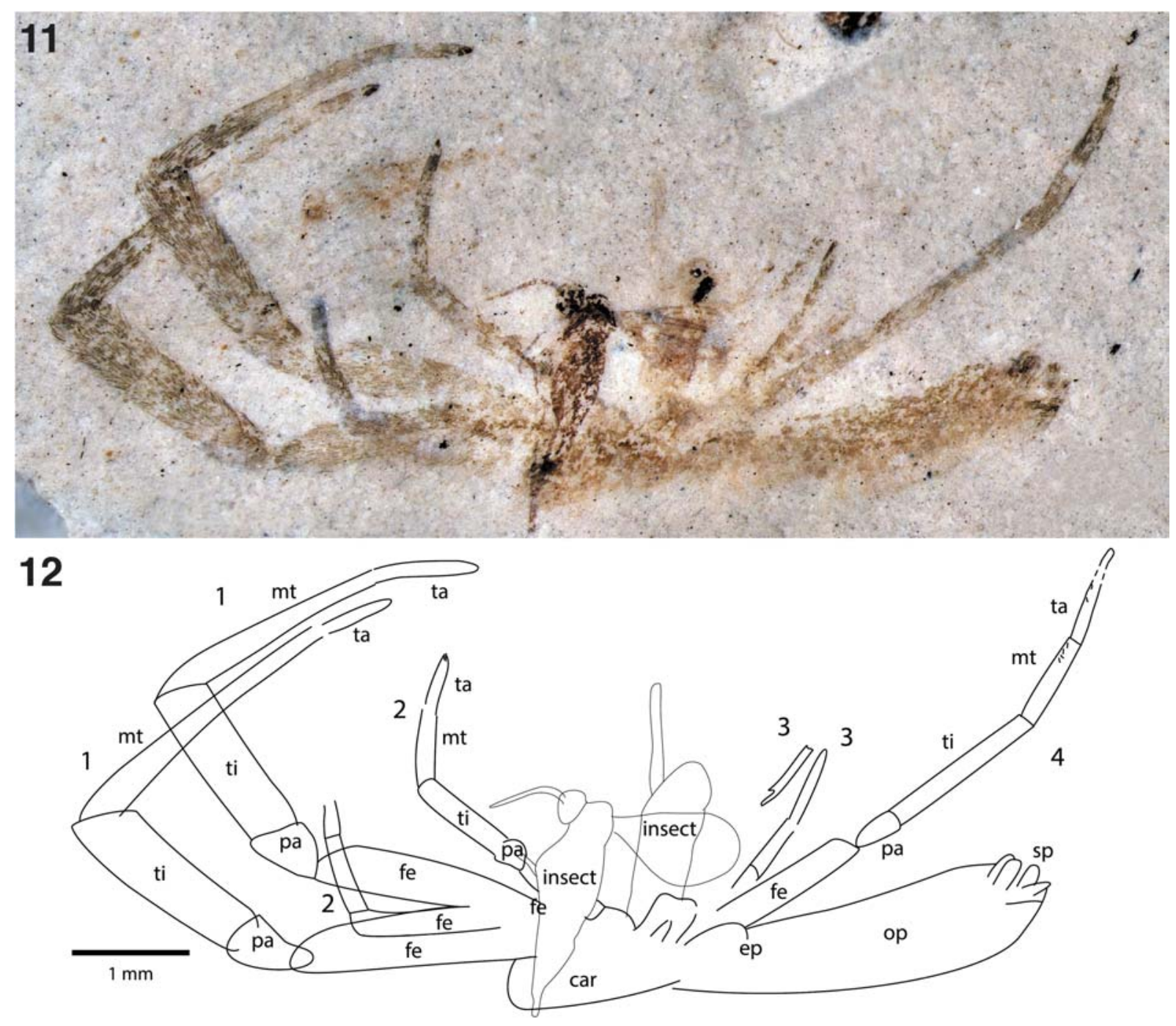

Figs 11-12. Miagrammopes sp., female, KUMIP 366473b (counterpart): 11 - photograph of whole specimen; 12 - explanatory drawing of 11 .

Рис. 11-12. Miagrammopes sp., самка, KUMIP 366473b (противоотпечаток): 11 - фотография всего тела; 12 - поясняющий рисунок фотографии 11.

However, some ground-dwelling hersiliids have rather shorter posterior spinnerets, and the fossil spider most closely resembles these. The common ground-dweller is Hersiliola (sensu lato, including e.g. Duninia Marusik et Fet, 2009, Ovtsharenkoia Marusik et Fet, 2009, Deltshevia Marusik et Fet, 2009) to which the fossil is referred. Occasional species in other genera have shorter spinnerets but these species differ in other ways from the fossil (e.g. Tamopsis brachycauda Baehr et Baehr, 1987 differs in the shape of the abdomen).

MATERIAL. KUMIP 366468 (male) from the Lower Eocene (Ypresian: 49-50 Ma) Parachute Creek Member of the Green River Formation, from Rio Blanco County, Colorado.

DESCRIPTION. KUMIP 366468 (Figs 20-22). Male. Small spider, body L 3.76 (inc. sp). Leg formula probably 2143; numerous macrosetae on at least proximal podomeres (fe-ti); podomere lengths: Leg I fe 1.67 , pa 0.48 , ti e"1.23, ta 0.52 ; Leg II fe 1.81 , pa 0.40 ; Leg III fe 0.98 , pa 0.38 , ti 0.98 , mt 0.71 , ta 0.66 . Op suboval L 1.73, W 1.24 (L/W ratio 1.39); sp terminal, PS L 0.87 , elongate, $2.8 \times$ length of AS, AS L 0.31 .

DESCRIPTION. KUMIP 366477 (Figs 23-27). Male. Small spider, body L 2.72 (inc. sp). Leg formula 2143; podomere lengths: Leg I fe 1.12, pa 0.26, ti 1.64, mt 1.51 , ta 0.45 ; Leg II fe 1.52 , pa 0.30 , ti 1.56 , mt 1.52, ta 0.51; Leg III fe 0.86, pa 0.29, ti 0.59, mt 0.57 , ta 0.39 ; Leg IV fe 1.29 , pa 0.29 , ti 0.80 . Op subcircular, about as wide as long, L 1.27, W 1.23 (L/W ratio 1.04); sp terminal, PS elongate, AS short.

\section{Family Selenopidae Simon, 1897}

Selenopidae incertae sedis

Figs 28-31.

REMARKS. Specimen KUMIP 366469 is identified as a selenopid on account of its laterigrade legs, 


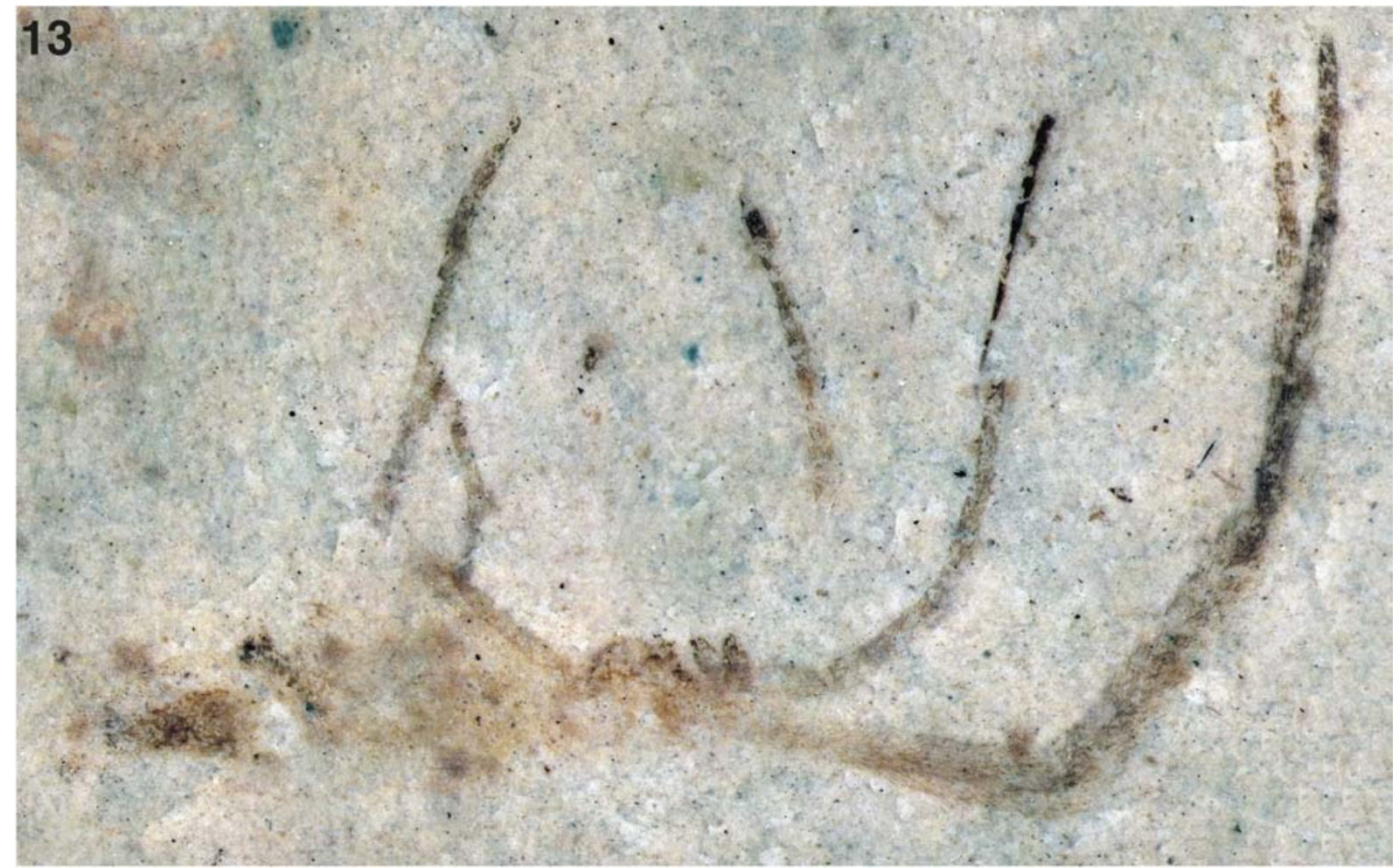

14

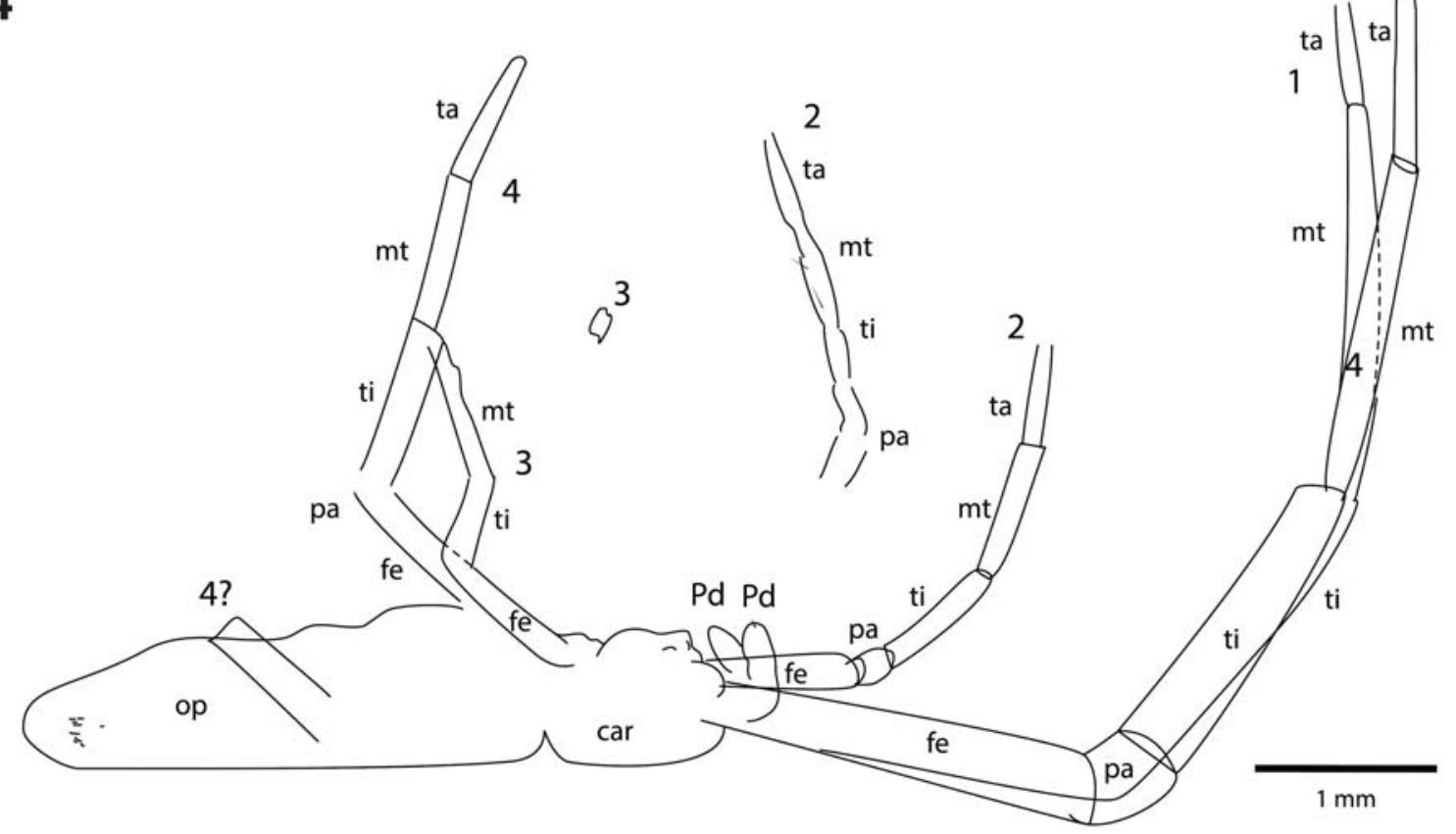
11.

Figs 13-14. Miagrammopes sp., subadult male, KUMIP 366474: 13 — photograph of whole specimen; 14 - explanatory drawing of фотографии 11. 

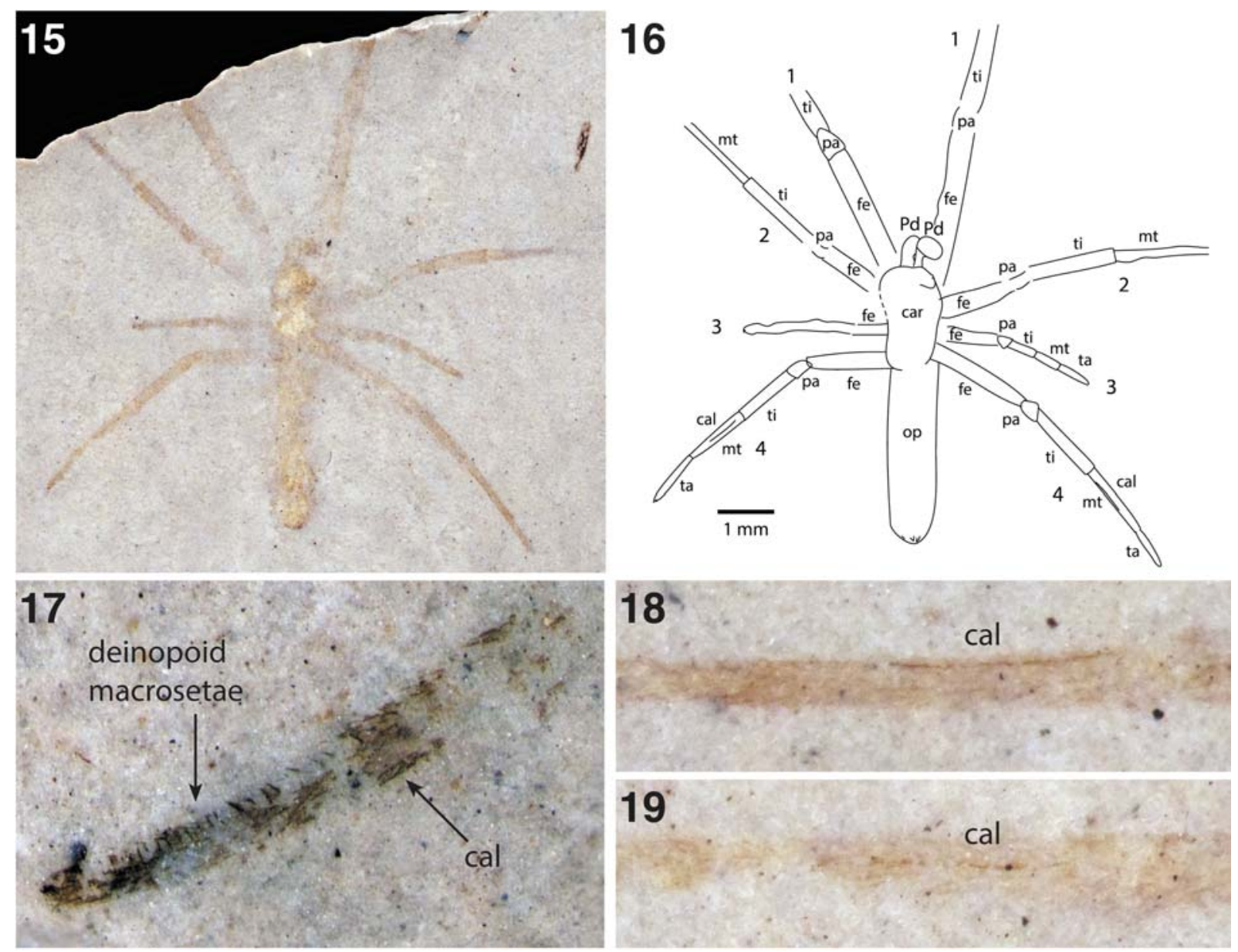

Figs 15-19. Miagrammopes sp., KUMIP 366475 (15-16, 18-19, subadult male), KUMIP 366473a (17, female): 15 — photograph of whole specimen; 16 - explanatory drawing of $15 ; 17$ - leg IV showing preserved section of calamistrum and row of deinopoid macrosetae along ventral edge of tarsus and distal part of metatarsus; 18-19 — right (18) and left (19) leg IV metatarsi showing remains of calamistra.

Рис. 15-19. Miagrammopes sp., KUMIP 366475 (15-16, 18-19, субадультный самец), KUMIP 366473a (17, самка): 15 фотография всего тела; 16 - поясняющий рисунок фотографии $15 ; 17$ - нога IV, показан участок каламиструма и ряд деинопидных щетинок вдоль нижнего края лапки и дистальной части предлапки; 18-19-правая (18) и левая (19) предлапка IV c остатками каламиструмов.

subequal in length; broad carapace; and numerous pairs of macrosetae on tibiae and metatarsi.

MATERIAL. KUMIP 366469 (female or juvenile) from the Lower Eocene (Ypresian: 49-50 Ma) Parachute Creek Member of the Green River Formation, from Rio Blanco County, Colorado.

DESCRIPTION. KUMIP 366469 (Figs 28-31).

Female or juvenile. Body length (inc. ch) 3.64. Car wider than long, L $1.27, \mathrm{~W} 1.58$ (L/W ratio 0.80$)$. Ch short, robust, with curved fang and row of small teeth on furrow, L 0.67. Pedipalp short, simple, pa 0.44 , ti 0.45 , ta 0.78 . Legs laterigrade, 3 and 4 slightly longer than 1 and 2, formula 4312; long macrosetae on femora-metatarsi, especially numerous on tibiae and metatarsi (e"3 pairs); thin, erect seta at c. 0.5 position on dorsal tibiae; tarsi rather short, weakly scopulate (Figs 28, 30, 32); podomere lengths: Leg I fe 1.79, pa 0.65, ti 1.99 , mt 1.47, ta 0.69 ; Leg II fe 1.66 , pa 0.66 , ti 1.87 , mt 1.23 , ta 0.76 ; Leg III fe 2.17 , pa 0.57 , ti $2.74, \mathrm{mt}$ 1.92, ta 0.79; Leg IV fe 1.80, pa 0.59, ti 2.49, mt 2.55, ta 0.96 . Op oval in outline, L 1.78, W $1.16(\mathrm{~L} / \mathrm{W}$ ratio 1.53); sp terminal, small.

\section{Family Thomisidae Sundevall, 1833}

\section{Thomisidae incertae sedis}

Figs 33-42.

REMARKS. These specimens (KUMIP 366470, $366471,366472)$ are identified as thomisids on account of their squat body (carapace and opisthosoma wider than long), triangular opisthosoma; legs 1 and 2 longer than legs 3 and 4, with two toothed claws and accessory serrate setae on the tarsi (cf. fig. $7 \mathrm{~K}$ in Wolff and Gorb [2012]), and a circular pedipalp with a marginal scimitar-shaped embolus. KUMIP 366470 and 366471 are adult males, while KUMIP 366472 is a juvenile; the last specimen is about the same size as the 

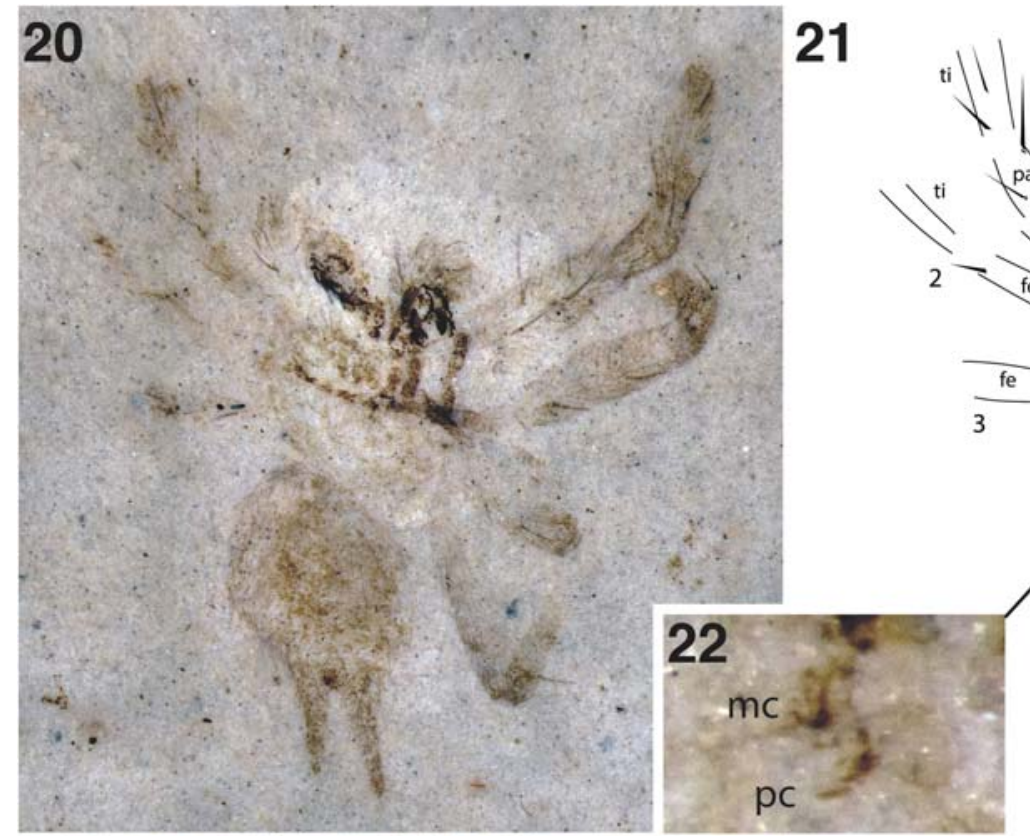

21
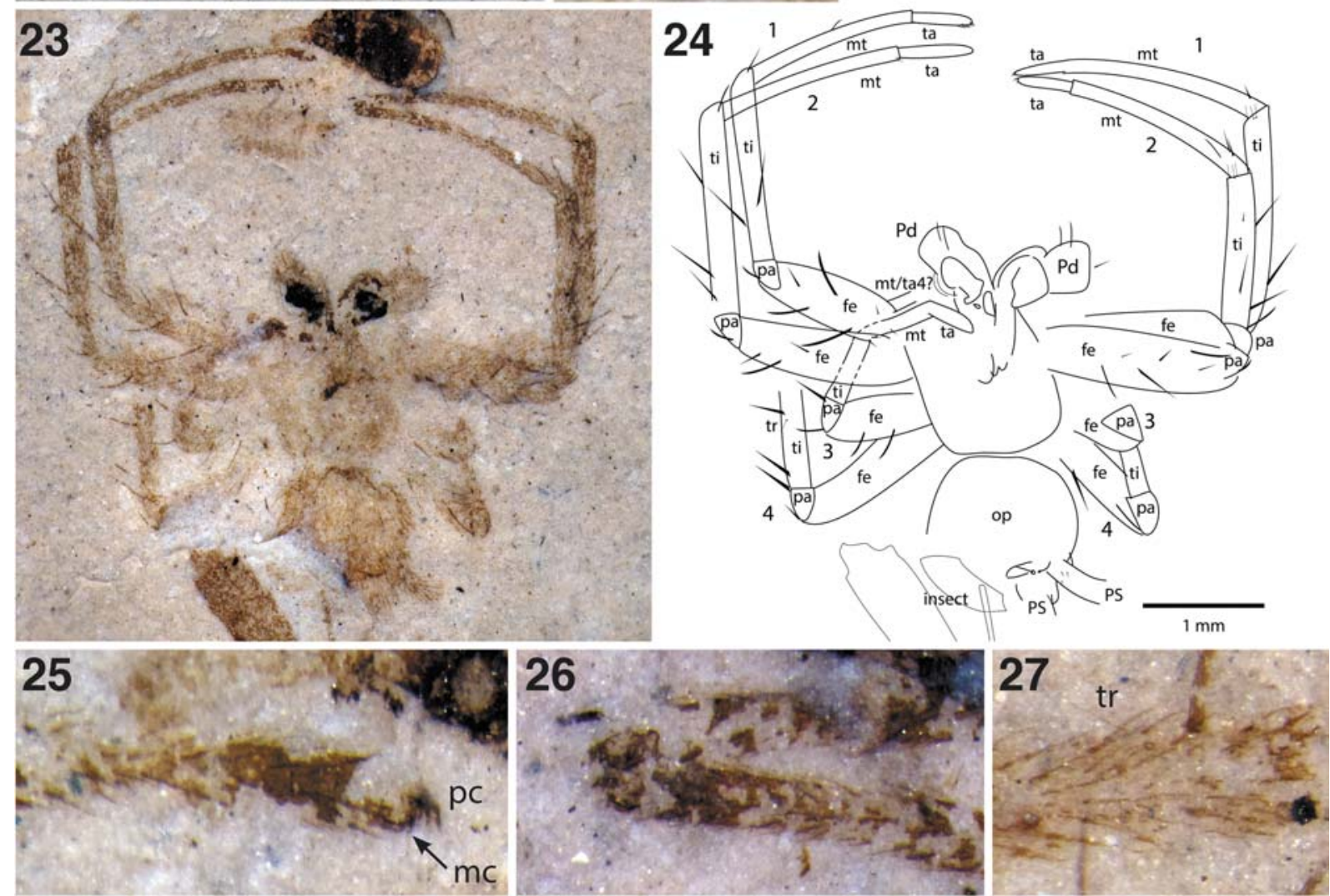

Figs 20-27. Hersiliola sp., males, KUMIP 366468 (20-22), KUMIP 366477 (23-27): 20, 23 - photographs of whole specimens; 21, 24 - explanatory drawings of 20 and 23, respectively; 22 - claws of left tarsus I; 25 - left tarsus I; 26 - right tarsi I and II; 27 trichobothrium on tibia of left leg IV.

Рис. 20-27. Hersiliola sp., самцы, KUMIP 366468 (20-22), KUMIP 366477 (23-27): 20, 23 — фотографии всего тела; 21, 24 поясняющие рисунки фотографии 20 и 23, соответственно; 22 - коготки левой лапки I; 25 - левая лапка I; 26 - правые лапки I и II; 27 - трихоботрия левой голени ноги IV. 

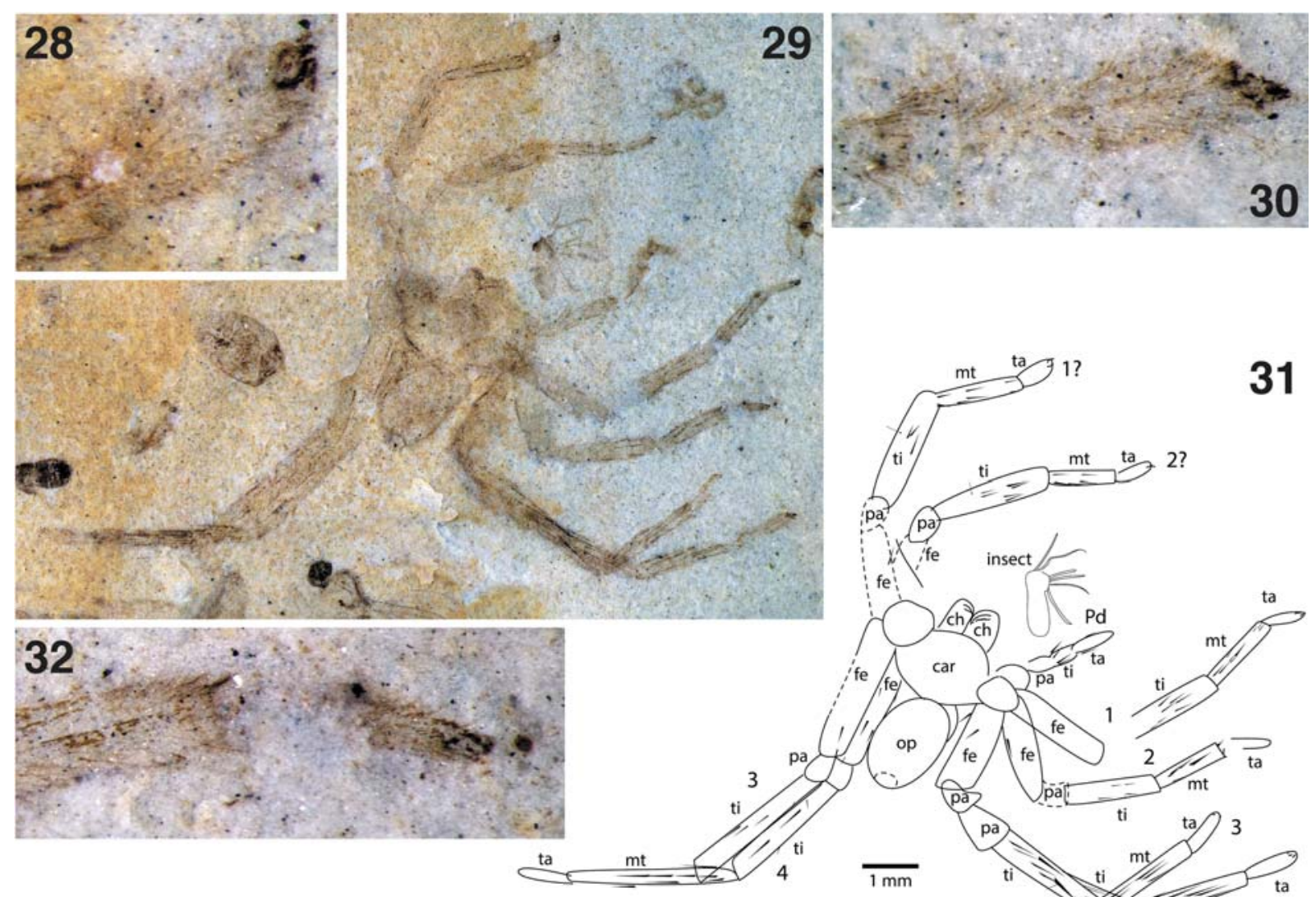

Figs 28-32. Selenopidae incertae sedis, female or juvenile, KUMIP 366469: 28 — left tarsus I; 29 — photograph of whole specimen; 30 - right tarsus IV; 31 - explanatory drawing of 29; 32 - right tarsus II.

Рис. 28-32. Selenopidae incertae sedis, самка или ювенил, KUMIP 366469: 28 — левая лапка I; 29 — фотография всего тела; 30 правая лапка IV; 31 - поясняющий рисунок фотографии 29; 32 - правая лапка II.

adult males, hence it is presumed to be a juvenile female. The short, triangular abdomen is characteristic of Thomisus Walckenaer, 1805, and the fossil species is most likely within the Thomisinae (or the Thomisus clade of [Benjamin et al., 2008]).

There are some differences between the fossil and Thomisidae, however: the anterior legs podomeres are not armed with strong macrosetae ventrally, which is common in thomisids, and the third leg is rather short. These characters are suggestive of male araneids; however, we are not aware of any araneids which have such a characteristic truncated abdomen as the fossil.

MATERIAL. KUMIP 366470a (part) and 366470b (counterpart), KUMIP 366471 (males), and KUMIP 366472 (juvenile) from the Lower Eocene (Ypresian: 49-50 Ma) Parachute Creek Member of the Green River Formation, from Rio Blanco County, Colorado.

DESCRIPTION. KUMIP 366470 (Male). Short, squat spider; car L 1.12, W 1.23 (L/W ratio 0.91). Pedipalp with scimitar-like embolus in marginal position (Figs 35-36). Legs 1 and 2 longer than 3 and 4, formula 1243; long macrosetae on dorsal distal patellae (position c. 0.99 ), and 0.25 and 0.75 of dorsal tibiae; tarsi with two, dentate claws (Fig. 39) and serrate setae; podomere lengths: Pd ta 0.38; Leg I fe 1.64, pa 0.39 , ti 1.15 , mt 1.32 , ta 0.59 ; Leg II fe 1.22 , pa 0.36 , ti 1.05 , mt 1.14 , ta 0.44 ; Leg III fe 0.71 , pa 0.28 , ti 0.52 , mt 0.56 , ta 0.44 ; Leg IV fe 1.20 , pa 0.34 , ti 0.71 , mt 0.95 , ta 0.38 . Opisthosoma triangular, with lateral sides slightly curved outwards, posterior edge almost straight, L $0.78, \mathrm{~W} 1.43$ (L/W ratio 0.55$)$.

DESCRIPTION. KUMIP 366471 (Male). Short, squat spider. Pedipalp with scimitar-like embolus in marginal position, Pd ta 0.42 . Leg formula 1243 ; long macrosetae on dorsal distal patellae (position c. 0.99), and approximately 0.25 and 0.75 of dorsal tibiae, smaller macrosetae on femur and metatarsus; tarsi with two, dentate claws (Fig. 40) and serrate setae; podomere lengths: Leg I pa 0.43, ti 1.21, mt 1.46, ta 0.77; Leg II pa 0.42 , ti 1.19 , mt 1.05 , ta 0.60 ; Leg III mt 0.58 , ta 0.45 ; Leg IV pa 0.30 , ti 0.74 , mt 0.96 , ta 0.48 . Opisthosoma triangular, with lateral sides slightly curved outwards, posterior edge almost straight.

DESCRIPTION. KUMIP 366472 (Juvenile female). Short, squat spider (Figs 41-42). Ch L 1.04. Pedipalp not swollen, fe 0.68 , pa 0.26 , ti 0.36 , ta 0.66 . Legs short, formula 1243; no large macrosetae; podomere lengths: Leg I fe 1.16, pa 0.46, ti 1.20, mt 1.20, ta 0.58; 

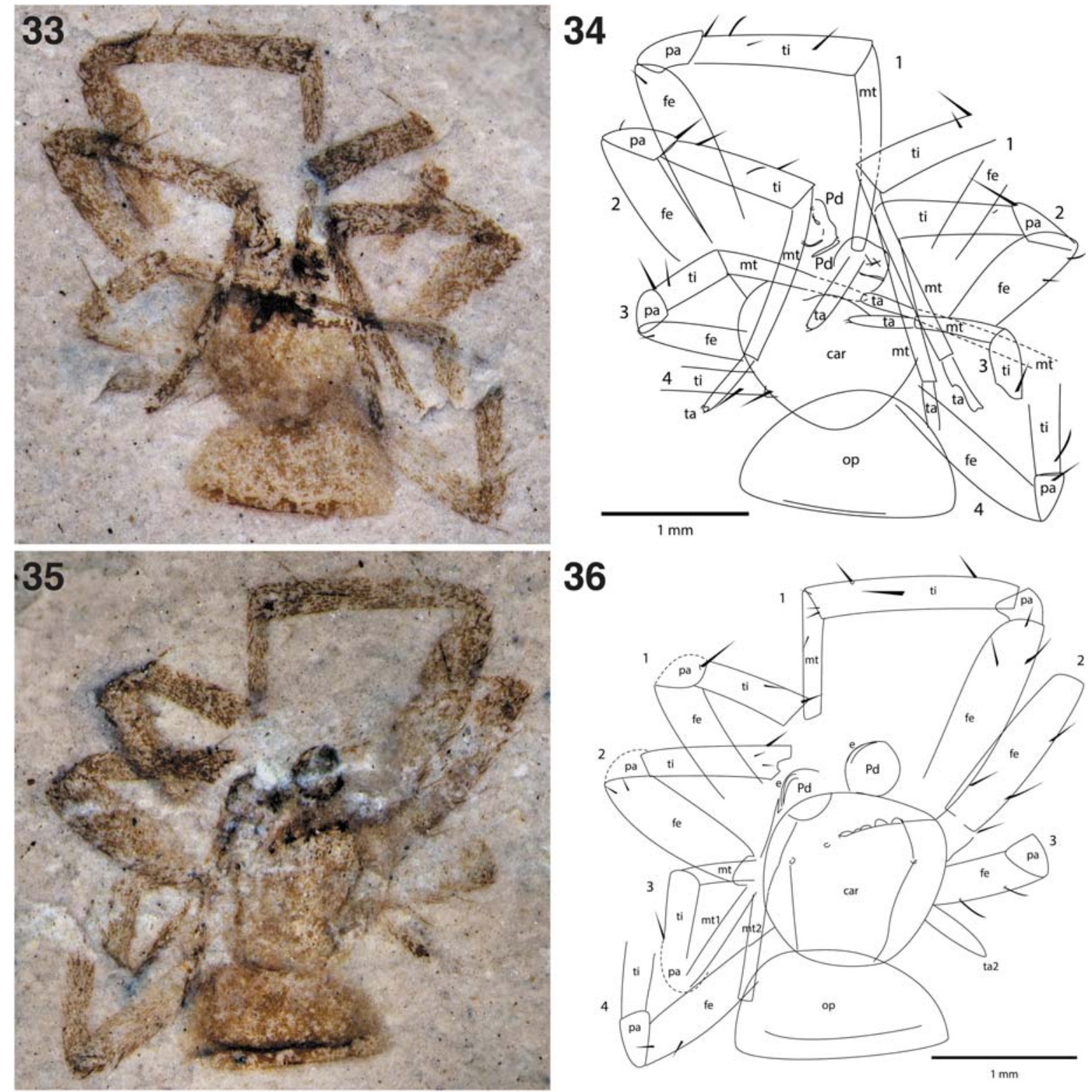

Figs 33-36. Thomisidae incertae sedis, male, KUMIP 366470a (part, 33-34), KUMIP 366470b (counterpart, 35-36): 33, 35 photographs of whole specimens; 34,36 - explanatory drawings of 33 and 35, respectively.

Pис. 33-36. Thomisidae incertae sedis, самец, KUMIP 366470a (отпечаток, 33-34), KUMIP 366470b (противоотпечаток, 35-36): 33,35 - фотографии всего тела; 34, 36 - поясняющие рисунки фотографий 33 и 35, соответственно.

Leg II fe 1.07, pa 0.51, ti 0.94, mt 0.65, ta 0.81; Leg III fe 0.83 , pa 0.39 , ti 0.59 , mt 0.54 , ta 0.42 ; Leg IV fe 1.11 , pa 0.40 , ti 0.83 , mt 0.90 , ta 0.51 . Opisthosoma triangular, L 1.94, height 2.33 .

\section{Discussion}

The ten specimens of spiders belong to four families (Hersiliidae, Selenopidae, Thomisidae, Uloboridae) which are diverse in their modes of life and habitats. Uloboridae weave aerial webs, mostly orbs but, in the case of Miagrammopes, single-line webs, among low vegetation in tropical forest habitats [Opell, 1984]. The other three families are surface dwellers, ranging from modes of life on the ground and under stones, to roamers on low or high vegetation. The fossil thomisid species most resembles the living Thomisus, which is a sit-and-wait predator on flowers, while the hersiliid is identified as a Hersiliola, which live under stones. Thomisids are cosmopolitan in distribution, while hersiliids and selenopids are essentially tropical and subtropical [Jocqué \& Dippenaar-Schoeman, 2006; Crews \& Harvey, 2011].

Such a diverse assemblage of spiders seems to represent a variety of habitats and modes of life: predomi- 

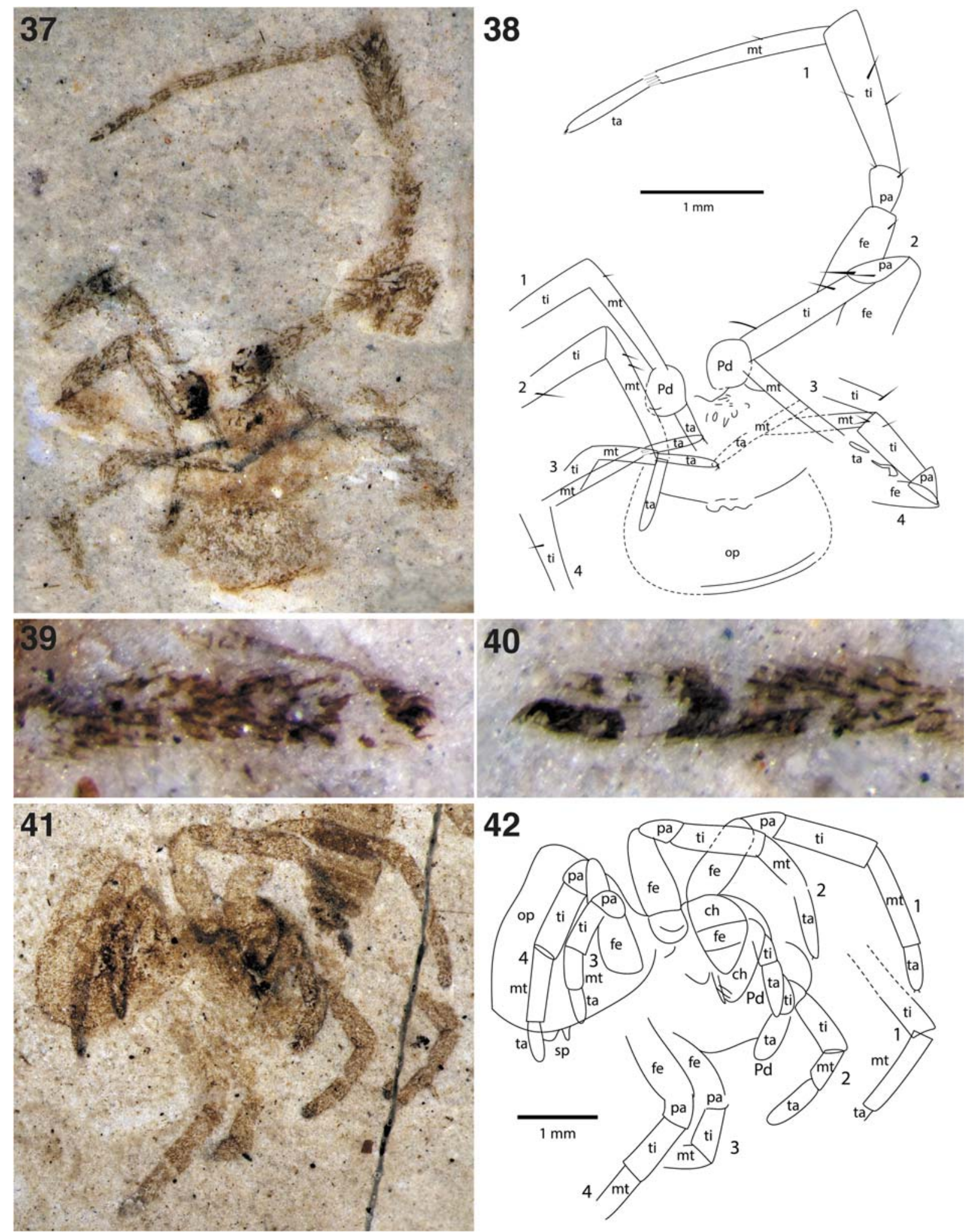

Figs 37-42. Thomisidae incertae sedis, KUMIP 366471 (37-38, 40, male), KUMIP 366470b (39, male), KUMIP 366472 (41-42, juvenile): 37,41 - photographs of whole specimens; 38,42 - explanatory drawings of 37 and 41 , respectively; 39 - left tarsus II; 40 right tarsus I.

Pис. 37-42. Thomisidae incertae sedis, KUMIP 366471 (37-38, 40, самец), KUMIP 366470b (39, самец), KUMIP 366472 (41-42, ювенил): 37, 41 - фотографии всего тела; 38, 42 - поясняющие рисунки фотографий 37 и 41, соответственно; 39 - левая лапка II; 40 - правая лапка I. 
nantly ground-dwellers, but including at least two species of web weavers. Sedimentological evidence of interbedded oil-bearing shales and evaporites (predominantly nahcolite and halite) suggests an intermittent playa lake environment [Lundell \& Surdam, 1975; Smith et al., 2008]. Presumably, the spiders were living in adjacent habitats and were washed into the lake during storms and subsequent flash floods. The provenance of the spiders may have been a lush forest, as evidenced by the subtropical vegetation and associated fauna (e.g crocodiles), rather than nearby salt flats, although a mixture of sources is quite likely.

\section{Conclusions}

The several species of spiders, belonging to the Uloboridae, Hersiliidae, Selenopidae, and Thomisidae described here are among the oldest records of their respective taxa. This arachnofauna consist of species from a variety of habitats and modes of life, was most likely thrown together during flash flood episodes, resulting in their deposition on the Green River playa lake. There are many more specimens of spiders from the Green River Formation available for study, some of which will be better preserved and will most likely reveal a greater diversity of spiders from the earliest Eocene, and thus provide further evidence for the palaeoclimate during this period of Earth history.

ACKNOWLEDGEMENTS. We thank Úna Farrell for accessioning the specimens to the collections of KUMIP; the Alexander von Humboldt Foundation for funding the sabbatical research visit to Berlin; and Yuri Marusik, Jörg Wunderlich, Peter Jäger and Jason Dunlop for helpful comments and discussions.

\section{References}

Baehr B., Baehr M. 1987. The Australian Hersiliidae // Invertebrate Taxonomy. Vol.1. P.351-437.

Benjamin S.P., Dimitrov D., Gillespie R.G., Hormiga G. 2008 Family ties: molecular phylogeny of crab spiders (Araneae: Thomisidae) // Cladistics. Vol.24. P.708-722.

Bertkau P. 1878. Einige Spinnen und ein Myriapode aus der Braunkohle von Rott // Verhandlungen des Naturhistorischen Vereins der Preussischen Rheinlande und Westfalens. Vol.35. P.346360 , pl. 5.

Bradley W.H. 1931. Origin and microfossils of the oil shale of the Green River formation of Colorado and Utah // US Geological Survey Professional Papers. Vol.168. P. i-v,1-58.

Cockerell T.D.A. 1925. Fossil insects in the United States National Museum. Proceedings of the US National Museum. Vol.64. P.1-17.

Codington L.A. 1995. Note on a possible spiderweb from Douglas Pass, Colorado // Averett W.R. (ed.). The Green River Formation in Piceance Creek and Eastern Uinta Basins Field Trip, 1995. Grand Junction, CO: Grand Junction Geological Society, Grand Junction, Colorado. P.117-118.

Crews S., Harvey M.S. 2011. The spider family Selenopidae (Arachnida, Araneae) in Australia and Asia // ZooKeys. Vol.99. P.1103.
Dayvault R.D., Codington L.A., Kohls D., Hawes W.D., Ott P.M. 1995. Fossil insects and spiders from three locations in the Green River Formation of the Piceance Creek Basin, Colorado // Averett W.R. (ed.). The Green River Formation in Piceance Creek and Eastern Uinta Basins Field Trip, 1995. Grand Junction, CO: Grand Junction Geological Society, Grand Junction, Colorado. P.97-116.

Downen M., Selden P.A. 2013. Using spider taphonomy to decipher the paleosalinity of the Crato Formation // Geological Society of America. Abstracts with Programs. Vol.45. P.317.

Dunlop J.A., Penney D., Jekel D. 2014. A summary list of fossil spiders and their relatives. // Platnick N.I. (ed.). The world spider catalog, version 14.5. New York: American Museum of Natural History, online at http://research.amnh.org/entomology/spiders/catalog/index.html.

Grande L. 2013. The lost world of Fossil Lake. Chicago: University of Chicago Press. 437 p.

Griswold C.E., Ramírez M.J., Coddington J.A., Platnick N.I. 2005. Atlas of phylogenetic data for entelegyne spiders (Araneae: Araneomorphae: Entelegynae) with comments on their phylogeny // Proceedings of the California Academy of Sciences. Vol.56. Supplement II. P.1-324.

Jocqué R., Dippenaar-Schoeman A.S. 2006. Spider families of the world. Tervuren, Belgium: Musée Royal de l'Afrique Centrale. $336 \mathrm{p} ., 32 \mathrm{pl}$

Lundell L.L., Surdam R.C. 1975. Playa-lake deposition: Green River Formation, Piceance Creek Basin, Colorado // Geology. Vol.3. P.493-497.

Nel A., Brasero N. 2010. Oise amber. // Penney D. (ed.). Biodiversity of fossils in amber from the major world deposits. Manchester: Siri Scientific Press. P.137-148.

Nudds J., Selden P.A. 2008. Fossil ecosystems of North America. London: Manson. 288 p.

Opell B.D. 1979. Revision of the genera and tropical American species of the spider family Uloboridae // Bulletin of the Museum of Comparative Zoology. Vol.148. P.443-549.

Opell B.D. 1984. Phylogenetic review of the genus Miagrammopes (sensu lato) (Araneae, Uloboridae) // Journal of Arachnology. Vol.12. P.229-240.

Penney D. 2006. The oldest fossil pholcid and selenopid spiders (Araneae) in Lowermost Eocene amber from the Paris Basin, France // Journal of Arachnology. Vol.34. P.592-598.

Santiago-Blay J.A., Soleglad M.E., Fet V. 2004. A redescription and family placement of Uintascorpio Perry, 1995 from the Parachute Creek Member of the Green River Formation (Middle Eocene) of Colorado, USA (Scorpiones: Buthidae) // Revista Ibérica de Aracnología. Vol.10. P.7-16.

Scudder S.H. 1890. The Tertiary insects of North America // United States Geological Survey of the Territories. Vol.13. P.1-734.

Selden P.A., Beattie R.G. 2013. A spider fossil from the Jurassic Talbragar Fossil Fish Bed of New South Wales // Alcheringa. Vol.37. P.203-208.

Smith M.E., Carroll A.R., Singer B.S. 2008. Synoptic reconstruction of a major ancient lake system: Eocene Green River Formation, western United States // Geological Society of America Bulletin Vol.120. P.54-84.

Weitschat W., Wichard W. 2010. Baltic amber // Penney D. (ed.). Biodiversity of fossils in amber from the major world deposits. Manchester: Siri Scientific Press. P.80-115.

Wolff J.O., Gorb S.N. 2012. Comparative morphology of pretarsal scopulae in eleven spider families // Arthropod Structure \& Development. Vol.41. P.419-433.

Wunderlich J. 2011. Some fossil spiders in Cretaceous ambers // Beiträge zur Araneologie. Vol.6. P.539- 557.

Responsible editor Yu.M. Marusik 